\title{
Collective Identity, Anglo-Saxon Bond and the Persistence of the Anglo-American Special Relationship
}

\author{
Ruike Xu \\ University of Nottingham, United Kingdom \\ xuruike8614@hotmail.com
}

\begin{abstract}
There have been many "end of affair" comments on the Anglo-American special relationship (AASR) in the post-Cold War era. Notwithstanding this, the AASR has managed to persist without losing its vitality up to the present. This article seeks to explain the persistence of the AASR from the perspective of collective identity. It argues that a strong Anglo-American collective identity has been an indispensable positive contributor to the persistence of the AASR after the end of the Cold War. The strong AngloAmerican collective identity facilitates Anglo-American common threat perceptions, solidifies embedded trust between the UK and the USA, and prescribes norms of appropriate behaviour for these two countries.
\end{abstract}

Keywords: collective identity, the UK, the USA, special relationship, trust

\section{Introduction}

Identity is socially constructed, allowing actors to be "recognized as something particular vis-à-vis others" (Eder, 2009, p. 428). It impacts how actors view the world and define their interests. Policymakers of states are not purely rational in the realist sense. They are not robots programmed to act purely rational in world affairs in pursuit of their cold-hearted national interests. In fact, their worldview and perception of national interests are unavoidably shaped by their own identity. The identity of a policymaker is reflected by the values he or she adheres to. It turns out to be rather difficult for policymakers in any country "to step outside of themselves when judging others. And they have rarely realized how much their own values unconsciously smudged the lenses through which they viewed the world" (Stuart, 1988, p. xiii).

Collective identity establishes a demarcation between friends and foes. It creates affinity and similarity among its in-group members, and strangeness and difference between itself and out-group outsiders (Eisenstadt and Giesen, 1995, p. 74). Collective identity not only defines who we are, but also delineates the boundaries against the others (Risse-Kappen, 1996, pp. 366-367). Collective identity is important, because it is "the sense of us" that enables states to define their common interests in a particular manner (Gibbins, 2014, p. 4).

This article explores the strength of Anglo-American collective identity and what role it plays in strengthening the persistence of the AASR. In order to fully analyse the influence of collective identity on the persistence of the AASR, this article unfolds in the following sections. First, it illuminates contributors to Anglo-American collective identity. Second, it measures the strength of Anglo-American collective identity by drawing on public opinion polls and discourse analysis of speeches of the Presidents and the Prime Ministers since 1991. Third, it elucidates how Anglo-American collective identity facilitates the persistence of the AASR in the post-Cold War era. The conclusion follows in the last section.

\section{Contributors to Anglo-American Collective Identity}

Common sentiments are an indispensable contributor to Anglo-American collective identity. Anglo-American common sentiments refer mainly to common language, common historical heritage, common values, and common popular culture. English is the common language for the UK and the USA, despite that the American English and British English have some subtle differences. The UK is not the only country who shares a common language with the USA. Canada, Australia, Ireland, New Zealand, Jamaica, Guyana, Barbados, Saint Vincent and the Grenadines, Grenada, Dominica and Palau are also English-speaking countries (Crystal, 2003, p. 109). However, among these English-speaking countries the UK is the most important ally of the USA. 
Common language facilitates mutual understanding, and enables the UK and the USA to have "more extensive and more intensive communication than would otherwise have been possible" (Reynolds, 1986, p. 6). Even though common language cannot always guarantee an easy-going relationship, it makes Anglo-American relationship "easier to make up, mend fences and carry on" (Parsons, 2002, p. 461).

Apart from facilitation of communication and mutual understanding, common language also cultivates common values. According to Reynolds (1989, p. 100), "Through that common language a common liberal inheritance was transmitted and then transformed". The UK and the USA are two liberal democracies, sharing similar political values. In fact, American democracy emanates from British traditions (Churchill, 1946).

Due to their shared historical heritage, the UK and the USA enjoy common values, such as democracy, freedom, rule of law and human rights up to the present. Both of them are active upholders of these common values. However, these AngloAmerican common values should not be taken for granted. As a matter of fact, before the late $19^{\text {th }}$ century, it was hard to identity their common values.

Before the late $19^{\text {th }}$ century, the USA constantly identified Britain as a "significant other", associating the British with aristocracy, tyranny, monarchy and empire, which are characteristics inimical to American democracy and liberty. To the Americans at that time, the British values were alien to their values. What was prevalent in that period was "a historical hostility to the British oppression which had provoked so many American symbols of patriotic pride from the Declaration of Independence to the Star Spangled Banner" (Strout, 1963, p. 134). The anti-British nationalism was prevalent in the USA (Crapol, 1973, p. 4).

For the British during that period, they regarded the American way of lifestyle as vulgar and less civilized, and viewed slavery in the American society with disdain (Burk, 2007, p. 278). The mutually unfavourable feelings between the UK and the USA made the already tense relationship more likely to slip into conflicts, since both of them tended to think the worst of each other when they disputed.

Values are not static. Rather, they are socially constructed and can be changed by society. Due to the social changes occurred in the USA and the UK in the second half of the $19^{\text {th }}$ century, the Americans and the British started to share more common values. On the one hand, the Americans ended slavery in the Civil War and hence ameliorated the negative attitudes of the British towards the Americans. On the other hand, there were more Americans showing favourable feelings to the British due to the gradual democratization of the British society since the implementation of the 1832 Reform Bill (Campbell, 1974, p. 203).

The changed attitudes between these two countries gave rise to a new sense of Anglo-Saxonism, "a discourse of racialized identity that obliged the British and American elites to think of themselves as the twin vanguards of modernity" (Vucetic, 2009, p. 24). To some extent, the emergence of Anglo-Saxonism helped pave the way for "the Great Rapprochement" (Perkins, 1968). However, British colonialism was still hated by most Americans when the British maintained their empire. As Moser (1999, p. 2) puts it, "If colonialism and wars of conquest were institutions which Americans claimed to despise, the British were unquestionably closely wedded to both". The gradual dissolution of the British Empire after the Second World War removed the last heavy stumbling block which jeopardized the further solidification of Anglo-American collective identity. After the British relinquished their empire, Anglophobia has been no longer powerful enough to drift apart AngloAmerican solidarity.

The Americans and the British have a lot in common in the popular culture. Literature is transferred across the Atlantic Ocean, as evidenced by the appeal of British authors such as William Shakespeare, Charles Dickens, J. R. R. Tolkien, Jackie Collins, and J.K. Rowling in the USA, and American authors such as Harriet Beecher Stowe, Mark Twain, Ernest Hemingway and Dan Brown in the UK. Any frequent traveller will have noticed the striking overlap of bestsellers on offer at airport bookstores, whether in London or Washington or New York. Many formats for new TV programmes shown across the USA originate in the UK while American popular culture from TV, music, film and fashion permeates British cultural life imperceptibly due to the common language and shared cultural heritage (House of Commons Foreign Affairs Committee, 2010, p. Ev129). The level of shared popular culture is huge. The fact that governments and publics of the UK and the USA can understand each other with minimal explanation results in a huge level of shared culture (House of Commons Foreign Affairs Committee, 2010, p. Ev115).

Apart from common sentiments, the other contributor of Anglo-American collective identity is the repeated cooperative acts. Common sentiments do not guarantee the formation of a strong collective identity. Only by repeated cooperative acts could 
common sentiments be positively constructed in contributing to a strong collective identity. There have been abundant cases of cooperative acts in Anglo-American relations in the realm of intelligence, nuclear and military affairs.

Common sentiments and repeated cooperative acts mutually reinforce each other. Common sentiments facilitate implementation of cooperative acts and repeated cooperative acts in turn strengthen the positive representation of common sentiments. Both are indispensable contributors to Anglo-American collective identity. On the one hand, without common sentiments, it is hard for states to constantly engage in cooperative acts over a long period of time. Stark circumstances like the Second World War could push Britain and the Soviet Union to put aside their sentimental differences. However, such stark circumstances are rare in international relations. In most cases, sentiments greatly matter. Sentimental commonality cannot always guarantee intimate cooperation. But sentimental differences could prevent states from engaging in long-term robust cooperation.

On the other hand, without repeated cooperative acts, the positive representation of common sentiments may fade into insignificance in the preservation of a strong collective identity. On account of repeated cooperative acts which had occurred over the better part of the $20^{\text {th }}$ century, President Clinton pointed out in November 1995 that, "We (the USA and the UK) overcame the legacy of our differences. We discovered our common heritage again, and even more important, we rediscovered our shared values" (Clinton, 1995). Cooperative acts between the UK and the USA enhance their favourable feelings to each other and hence strengthen the positive representation of common sentiments.

\section{Strength of Anglo-American Collective Identity}

This section seeks to measure the strength of Anglo-American collective identity in the perception of both the public and political elites. Collective identity is nebulous and inherently difficult to measure. But its strength can be assessed by making use of public opinion polls which investigate people's opinion towards other countries and political speeches delivered by leaders of the UK and the USA.

\section{Public Perception of Anglo-American Collective Identity}

People in countries which share strong collective identity tend to have more favourable feelings toward each other. They are more likely to trust each other and consequently regard each other as their reliable ally. The more mutually favourable feeling they have, the stronger their collective identity is. This subsection utilizes public opinion polls conducted by widely respected polling organizations, such as the Chicago Council on Global Affairs, Gallup, Pew Research Centre. The purpose of drawing on polling data from more than one organization is to minimise anomaly and possible inaccuracy in the public opinion polls as much as possible. By using different public opinion polls conducted by different organizations from different time periods, dangers of distortion in the public opinion polls could be significantly decreased.

\section{Public Opinion Polls of the Chicago Council on Global Affairs}

In public opinion polls of the Chicago Council on Global Affairs, the mean score is on a scale of 0 to 100 , with 100 meaning a very warm, favourable feeling, 0 meaning a very cold, unfavourable feeling, and 50 meaning not particularly warm or cold. From 1978 to 2002, the UK had been the Americans' second most favourable country following Canada. Since 2004, Canada has not been included in the sample of surveys. As a result, the UK has been the most favourable country for the Americans among the surveyed countries (see Figure 1).

The above graph shows clearly that the Americans had comparatively more favourable feelings to the UK than to France, Germany and Israel from 1990 to 2010. During this period, the mean temperature of warmth of the American people on the UK was roughly $72^{\circ} \mathrm{C}$ in comparison with $59^{\circ} \mathrm{C}$ of Germany and $52.8^{\circ} \mathrm{C}$ of France. From the survey data prepared by the Chicago Council on Global Affairs, the UK has been the most trustworthy European power of the USA in the post-Cold War era. It is widely argued that Israeli-American special relationship is the strongest competitor of the Anglo-American special relationship. Between 1990 and 2010 , the mean temperature of warmth of the Americans on Israel was $54.8^{\circ} \mathrm{C}$, far lower than that of the UK. Countries hostile to the USA tended to get low "temperature of warmth" of the American people. For instance, the "temperature of warmth" of the American people on Iran and North Korea were $27^{\circ} \mathrm{C}$ respectively, the lowest among the surveyed states in 2010. 


\section{The Gallup Public Opinion Polls}

Gallup has conducted annual public opinion polls on how the American people view other countries for the past decades. There are four options available for interviewees to choose regarding a particular country: very favourable, mostly favourable, mostly unfavourable and very unfavourable. Between 2003 and 2013, the UK was viewed as one of the top two favourable countries for the American people (see Figure 2).

According to the above graph, the UK was the second most favourable countries surpassed only by Canada in the period 2003-2013. The mean percentages of the American people's favourability of these mentioned countries in the graph were as follows: Canada, 90.4\%; the UK, 88.3\%; Germany, 78.6\%; Israel, 66.5\%; France, $62 \%$. Such results are in concordance with the surveys conducted by the Chicago Council on Global Affairs. The UK was the most favourable state among the big powers of Europe between 2003 and 2013. In addition, it seems that the American people showed more favourable feelings towards the Anglo-American special relationship than towards the Israeli-American special relationship.

\section{The Pew Research Centre Public Opinion Polls}

Since its inception in 2001, the Pew Global Attitudes Project has conducted surveys across the world on people's opinion on the USA and the American people. The interviewees choose their own options from the following four options: very favourable, somewhat favourable, somewhat unfavourable and very unfavourable. Favourable combines "very favourable" and "somewhat favourable" while unfavourable combines "very unfavourable" and "somewhat unfavourable". On average, the British showed the most favourable feelings to the USA among the three big European powers in the period 2001-2012 (see Figure 3).

According to Figure 3 , the mean percentages of these three countries' favourable feelings towards the USA from 2002 to 2012 were the following: the UK, 61.2\%; France, 53.8\%; Germany, 46.7\%. The first outstanding feature in this graph is that the Bush administration's Iraqi policy was rather unpopular in these three countries, especially in France and Germany. After President Obama took office in 2009, these three countries had become significantly more pro-USA. The French people had more favourable feelings towards the USA under the Obama administration than the British, which in some degree demonstrated the high unpopularity the Bush administration in the eyes of the French. The second outstanding feature of this graph is that the British's favourable feelings to the USA were more stable over the 2002 through 2012 timeframe than that of the French and Germans. Attitudes of the French and Germans towards the USA fluctuated dramatically between 2002 and 2012.

By analysing the aforementioned four graphs, it is evident that people in the UK and the USA hold highly favourable feelings toward each other in the post-Cold War era, indicating that a strong "we-feeling" rooted in the collective identity exists between these two societies. Such a strong "we-feeling" provides the solid bedrock on which to base the special relationship between the UK and the USA (Rasmussen and McCormick, 1993, p. 518).

More importantly, these graphs demonstrate the stability and durability of favourable feelings between these two societies over an extended period of time, which to a large extent testifies to a stable and durable Anglo-American collective identity. Compared with France and Germany, the British favourable feelings fluctuated far less. Such stable and durable affinity between societies of the UK and the USA helps to keep the special relationship strong in the long run. The stable and durable mass sentiments between these two societies also serve as a cushion to alleviate the severity of Anglo-American discords, enabling the UK and the USA to heal wounds and recover from the damage quickly.

\section{Elite Perception of Anglo-American Collective Identity}

Political elites play a much larger role than the general public in shaping the destiny of the AASR. Their perception of AngloAmerican collective identity therefore deserves particular attention. As Hendershot $(2008$, p. 3) argues, "Sentimentality, or elite perception of cultural affinity, has been key to the durability of the special relationship".

Since Presidents and Prime Ministers play more crucial roles than other political elites in Anglo-American relations, it is more plausible to focus on how Presidents and Prime Ministers in the post-Cold War era think about the special relationship. This subsection makes use of speeches of four American Presidents and four British Prime Ministers in the post-Cold War era. Their speeches are analysed based on three criteria, including what words they use to describe the special relationship, 
what factors contribute to the special relationship from their viewpoints, and how they perceive the importance of the special relationship in the world (see Figure 4, Figure 5 and Figure 6).

By comparing what these four Presidents and four Prime Ministers said in their respective speeches, it is possible to recognize the tremendous similarity of their views on the special relationship. As the above tables show, there has been a bipartisan consensus on the special relationship both in the USA and in the UK since 1991. Even the hardened critics of the AASR could not deny the fact that the Presidents and the Prime Ministers in the post-Cold War era hold extraordinarily similar outlooks on the special relationship.

It is noteworthy to point out that by focusing on the speeches of Presidents and Prime Ministers, this section tries to illuminate to what extent a similar perception of the special relationship has been shared by leaders of the UK and the USA. It does not deal with the question that how personal relations of Presidents and Prime Ministers shape the special relationship. Personal chemistry between Prime Ministers and Presidents facilitates, to some extent, Anglo-American intimate cooperation, but cannot decide the destiny of the special relationship.

The special relationship has apparently outlived personal relationships between the two countries' political leaders. Prime Ministers and Presidents come and go, but the special relationship remains in place. Its longevity turns out not to be decisively influenced by personal relationships between political leaders. The special relationship has the ability to "transcend high-level differences of opinion and conflicting leader personalities" (Dumbrell, 2012, p. 307).

Notwithstanding the short time span of any given Prime Minister's or Presidency's term, by means of textual analysis of a host of speeches by Presidents and Prime Ministers on the special relationship, an enduring and consistent feature is revealed. A positive representation of the special relationship is pervasive in the speeches of Presidents and Prime Ministers. In terms of description of the special relationship, these Presidents and Prime Ministers held a positive view of the special relationship by using words such as "enduring", "unique", "extraordinary", "essential" and "vital", demonstrating their confidence in the persistence of the special relationship. In terms of the importance of the special relationship, all Presidents and Prime Ministers in the post-Cold War era considered the special relationship as a force for good in the world. In terms of the contributors to the special relationship, all of them highlighted Anglo-American shared culture and values.

The American presidents' regular and consistent rhetoric on the AASR are not "cheap talk". Rather, it reveals the genuine perceptions of the unparalleled intimacy between the UK and the USA. That all Presidents and Prime Ministers in the postCold War era have placed a high priority on common values reveals their shared sense of a strong collective identity. Given that speeches delivered by these Presidents and Prime Ministers also reflect, to the large extent, the general beliefs of the overall political elites, it could be safely concluded that the political elites of the UK and the USA also share a strong AngloAmerican collective identity especially in terms of shared values. Undeniably, the elite perception of the special relationship matters significantly. As Edwards and Sanders (1989, pp. 1-2) argue, "The attitudes of the elite, after all, represent a perceptual filter which conditions the way in which the behaviour of other states is interpreted: they constitute an important part of the make-up part of the key decision-makers".

In addition, the speeches delivered by two countries' leaders help consolidate Anglo-American collective identity by consistently emphasizing their collective memories about their joint sacrifice of blood and treasure in hard times (Digeser, 2009, p. 339). Such collective memories shared by two countries' political elites engender a strong sense of "we feeling" and togetherness. Prime Minister Cameron emphasized Anglo-American joint sacrifice of blood and treasure in the Second World War and the Korean War in a joint news conference with Obama on 25 May 2011. As he put it, "Barack and I know well the shared history of our countries. From the beaches of Normandy to the Imjin River, our soldiers have fought together" (Obama, 2011). Prime Minister Cameron's remarks resonated with what President Obama said in a welcoming ceremony for Cameron in the White House on 14 March 2012. When explaining the reasons why the rock-solid alliance of the USA and the UK became the constant feature of world affairs, he said that "the reason is simple. We stand together, and we work together, and we bleed together, and we build together, in good times and in bad" (Obama, 2012).

\section{Impact of Collective Identity on the Persistence of the AASR}

First, a strong collective identity contributes to US-UK common threat perceptions, thereby consolidating their highly compatible national interests. A strong collective identity cannot guarantee that the UK and the USA will act in concert for 
the sake of their common interests all the time. Occasionally, they disagree with each other. Their relationship reached a low point in the Bosnian War due to their disagreements over how to respond to the humanitarian disasters there. Notwithstanding this, the UK and the USA incline to see eye to eye on most international threats due to their strong collective identity. They are more often than not working together in harmony in the face of the international threats which put their interests and values in danger. Both the UK and the USA are the outward-looking countries, with global outlook and global interests in a plethora of areas. They share highly compatible security interests. When facing the out-group challengers, they tend to unite together and put aside their disputes if there are any, as indicated in the two World Wars and the Cold War (Bell, 1972, p. 106).

After 9/11, Islamist terrorism epitomized by AI Qaeda has become the most prominent threat for both the UK and the USA. Islamist terrorism not only threatens Anglo-American interests, but also poses a challenge to Western values and Western way of life. As Gove (2006, p. viii) argues, "Islamism poses a challenge to Western values, indeed to universal human values of freedom, dignity and equality, just as potent as past totalitarianisms". Hence, both the USA and UK feel threatened by Islamist terrorism and they have worked in tandem in dealing with such a serious threat since 9/11.

The UK and USA's shared concern about the proliferation of WMD amongst rouge and despotic states, as well as terrorist non-state actors, also has its roots in their collective identity. Both worry about a nuclear Iran and a nuclear North Korea, and have made efforts to prevent them from developing nuclear weapons, albeit with limited success. They were so worried about the potential threat of Saddam's Iraq armed with the purported WMD that they rushed to launch a preventive war with the aim of regime change in Iraq, creating a big foreign policy blunder after 9/11.

By contrast, the UK and the USA do not worry about each other's nuclear weapons. Both even enjoy the second-to-none nuclear cooperation. They also do not have a parallel fear of Israel's or India's nuclear weapons. It is not because nuclear weapons of North Korea or Iran (if it succeeds) are more powerful than those of Israel or India. Rather, it is because the UK and the USA have engrained distrust of the North Korea and Iran whose political values are alien to Western values. For the UK and the USA, North Korea and Iran are "out-group" strangers which cannot be trusted while Israel and India are "in-group" friends that can be trusted. Therefore, the UK and the USA are inclined to assume the worst scenario about the despotic states' nuclear weapons.

Second, a strong collective identity solidifies embedded trust between the UK and the USA, helping to sustain the longevity of the special relationship. Basically, there are two types of trust. The first type is trust-as-predictability, which refers to the scenario that "A trusts $B$ when A predicts that $B$ will at least do no harm in a circumstance in which A's interests depend on B's behaviour" (Hoffman, 2002, p. 379; Booth and Wheeler, 2008, p. 229). This type of trust is borne out of rational calculation.

The second type is trust-as-bond, which refers to the scenario that the trustor is confident that the trustee has moral obligation to fulfil the trust placed in it even if it means sacrificing some of their own interests (Hoffman, 2002, p. 379; Booth and Wheeler, 2008, p. 229). This type of trust is borne out of affinity and positive emotion rather than rational calculation. The trust-as-bond not only involves predictability, but also involves moral obligation and responsibility. The embedded trust between the UK and the USA is more analogous to trust-as-bond. Therefore, the AASR exemplifies normative international friendship, which "assumes that international friendship exists for normative and moral reasons as opposed to strategic calculations (Oelsner and Koschut, 2014, p. 14).

Due to the positive relationships between political leaders of these two countries and highly favourable feelings between these two societies, there exists embedded trust between the UK and the USA. Embedded trust extends beyond the intimate relationship at the elite level. It exists at the inter-societal level (Booth and Wheeler, 2008, p. 230). The strong collective identity gives rise to embedded trust between the UK and the USA. Embedded trust is more endurable and persistent than personal trust between political leaders. It is crucial to sustain the AASR in the changing world.

Embedded trust makes it easier for the UK and the USA to engage in long-term security cooperation. The AASR is a relationship "built on a long-lasting friendship between the two nations, involving cultural affinities and shared values, not just a marriage of convenience between states which happen to find their current interests aligned on the international stage" (Hawley, 2012, p. 107). Trust minimizes uncertainty, enabling the UK and the USA to keep their long-standing close cooperation against all the odds. Because of embedded trust, the UK and the USA are willing to "tolerate mutual vulnerability despite irreducible uncertainty about the other's motivations" (Kupchan, 2010, p. 49-50). 
States cannot escape from uncertainty. In the 1990s, the UK and the USA did not expect that they would unite together in the War on Terror after 9/11. Likewise, they do not know what will happen to them in decades ahead. On account of embedded trust, the UK and the USA can move rapidly to unite together against any challenges in the foreseeable future. Thus, they are highly likely to keep engaged in long-term security cooperation.

Apart from facilitating their long-term security cooperation, the presence of embedded trust also enables the UK and the USA to swiftly overcome their occasional disagreements. The AASR is not perfect. A strong collective identity cannot prevent discords from occurring between these two countries. Like any other relationships, the AASR also experiences ebb and flow. What makes the AASR exceptional is that all Anglo-American squabbles are temporary. A strong collective identity can prevent Anglo-American disputes from escalating into unrepairable crises. There has been no entrenched enmity between the UK and the USA. Embedded trust creates strong bonds between the UK and the USA, enabling them to empathize with each other. As a result, they consider their occasional disagreements as "family spats" between brothers (Hendershot, 2008). Family spats do not last long. Since both the UK and the USA regard each other as their trustworthy partner, they do not allow the occasional unhappy event to jeopardize their long-standing partnership.

Embedded distrust engenders an "inherent bad faith model" of an adversary (Holsti, 1967, p. 26). Relationship between the USA and Russia has been influenced by the "inherent bad faith model", preventing them from building trusting relationship after the end of the Cold War. Even though there has been no overt hostility to each other militarily, mutual distrust between the USA and Russia has apparently become more serious in recent years. By contrast, embedded trust gives rise to an "inherent good faith model" of a friend. In the post-Cold War era, the UK and the USA have constantly regarded each other as close friends.

Third, a strong collective identity prescribes norms of appropriate behaviour for the UK and the USA, pushing them to act in accordance with their collective identity. Both the UK and the USA believe that the AASR should be a force for good in the world. As liberal democracies, they should abide by international norms and uphold international law when engaging in military actions.

In reality, however, the UK and the USA acted in violation of what their collective identity required them to do under certain circumstances. They sometimes have to compromise their appropriate norms in pursuit of their so-called national interests. Whenever their actions violated their collective identity, the strong domestic pressure would push them to reorient their inappropriate policies. There were some cases in which the UK and the USA acted in contravention of their collective identity after 9/11, with Anglo-American collusion on torture as the most prominent example.

There have been allegations that the UK and the USA were complicit in the torture of suspected terrorists during the War on Terror. It remains unclear to what extent the UK was involved in torture. However, some evidence shows that the UK colluded with the USA on torture in some cases. The UK government publicly admitted for the first time that it had been involved in extraordinary rendition in February 2009 (BBC News, 2009). Moreover, the British intelligence agencies also "had directly colluded in the torture of various British suspects at interrogation centres in Egypt, Bangladesh and Pakistan" (Self, 2010, p. 222).

Anglo-American collusion on torture of suspected terrorists in the name of counter-terrorism tarnished the reputation of both the UK and the USA and squarely defied their collective identity. Due to the overt defiance of international law and human rights, it weakened the soft power of these two countries as a result. Because of the UK's complicity in torture, Prime Minister Cameron admitted that "our reputation as a country that believes in human rights, justice, fairness and the rule of law risks being tarnished" (The Detainee Inquiry, 2013, p. 2). Due to strong allegations from the public, both the UK and the USA eventually took measures to correct their errors with regard to torture. President Obama signed an executive order to outlaw torture in 2009.

The ethical aspect of the AASR should not be omitted. Both the UK and the USA have asserted that their special relationship is for the good of the world, contributing to the peace and justice of the international community. However, Anglo-American collusion on torture has eroded the special relationship's moral ground. A special relationship without solid moral footing will become weakened in the world. 


\section{Conclusion}

There exists a strong collective identity between the UK and the USA, which has played a unique role in helping sustain the AASR in the post-Cold War era. The strong Anglo-American collective identity facilitates the persistence of the special relationship by forging sustainable common threat perceptions, solidifying embedded trust and prescribing norms of appropriate behaviour.

The positive influence of Anglo-American collective identity, however, should not be exaggerated. A strong collective identity cannot guarantee a harmonious relationship between the UK and the USA all the time. After all, national identity remains stronger than transnational collective identity in either the UK or the USA. Thus, national interests of the UK and the USA cannot be perfectly aligned all the time.

Even though their national interests are aligned in certain cases, the strong collective identity cannot make sure that the UK and the USA have harmonious working relationships in dealing with their common concerns. On balance, a strong collective identity is a positive contributor to the AASR. It makes the UK and the USA only experience a rather small proportion of difficult times over the past decades, and in the meantime helps to avoid crises.

\section{References}

[1] Bartlett C.J. (1992). 'The Special Relationship’: A Political History of Anglo-American Relations since 1945. London: Longman.

[2] Baylis, John (1984). Anglo-American Defence Relations 1939-1984: The Special Relationship. London: Macmilian.

[3] BBC News (2009, 26 February) Minister Admits Terror Transfer. Retrieved from http://news.bbc.co.uk/1/hi/7912656.stm

[4] Bell, Coral (1972). The 'Special Relationship'. In Michael Leifer (Ed.), Constraints and Adjustments in British Foreign Policy (pp. 103-119). London: Allen \& Unwin.

[5] Booth, Ken and Wheeler, Nicholas (2008). The Security Dilemma: Fear, Cooperation and Trust in World Politics. Basingstoke: Palgrave Macmillan.

[6] Burk, Kathleen (2007). Old World, New World: Great Britain and America from the Beginning. London: Little Brown.

[7] Campbell, Charles S. (1974). From Revolution to Rapprochement: The United States and Great Britain, 1783-1900. New York: John Wiley \& Sons.

[8] Chicago Council on Global Affairs (2010). American Public Opinion and United States Foreign Policy Series. Retrieved from http://www.icpsr.umich.edu/icpsrweb/RCMD/series/00004

[9] Churchill, Winston (1946, 5 March). The Sinews of Peace. Retrieved from http://www.winstonchurchill.org/learn/speeches/speeches-of-winston-churchill/120-the-sinews-of-peace

[10] Clinton, William (1995, 29 November). Speech to the House of Parliament. Retrieved from http://www.johnmajor.co.uk/page1367.html

[11] Crapol, Edward P. (1973). America for Americans: Economic Nationalism and Anglophobia in the Late Nineteenth Century. Westport: Greenwood Press.

[12] Crystal, David (2003). English as a Global Language. Cambridge: Cambridge University Press.

[13] Digeser, P.E. (2009). Friendship between States. British Journal of Political Science, 39 (2), 323-344.

[14] Dobson, Alan (1995). Anglo-American Relations in the Twentieth Century: Of Friendship, Conflict and the Rise and Decline of Superpowers. London: Routledge.

[15] Dobson, Alan and Marsh, Steve (2014). Anglo-American Relations: End of a Special Relationship. The International History Review, 36 (4), 673-697.

[16] Dumbrell, John (2009). Hating Bush, Supporting Washington: George W. Bush, Anti-Americanism and the US-UK Special Relationship. In John Dumbrell and Alex R. Schäfer (Ed.), America's "Special Relationships": Foreign and Domestic Aspects of the Politics of Alliance (pp. 45-59). Abingdon: Taylor \& Francis. 
[17] Dumbrell, John (2012). Ambassadors Crowe and Lader, 1994-2001. In Alison R. Holmes and J. Simon Rofe (Ed.), The Embassy in Grosvenor Square: American Ambassadors to the United Kingdom, 1938-2008 (pp. 302-315). Basingstoke: Palgrave Macmillan.

[18] Eder, Klaus (2009). A Theory of Collective Identity: Making Sense of the Debate on a 'European Identity'. European Journal of Social Theory, 12(4), 427-447.

[19] Edwards, Geoffrey and Sanders, David (1989). British Elite Attitudes and the US: Continuity and Change. London: The Royal Institute of International Affairs.

[20] Eisenstadt, Shmuel Noah, and Giesen, Bernhard (1995). The Construction of Collective Identity. European Journal of Sociology, 36 (1), 72-102.

[21] Gallup Brain (2013). Gallup Poll Social Series: World Affairs, 2003-2013. Retrieved from https://institution.gallup.com/sorry/AccessDeniedlnstitution.aspx?r=/Brain/QuestionSearchResults.aspx

[22] Gibbins, Justin (2014). Britain, Europe and National Identity: Self and Other in International Relations. Houndmills: Palgrave Macmillan.

[23] Gove, Michael (2006). Celsius 7/7. London: Phoenix.

[24] Hawley, Katherine (2012). Trust: A Very Short Introduction. Oxford: Oxford University Press.

[25] Hendershot, Robert M. (2008). Family Spats: Perception, Illusion and Sentimentality in the Anglo-American Special Relationship, 1950-1976. Dudweiler Landstr: VDM Verlag Dr. Muller.

[26] Hoffman, Aaron (2002). A Conceptualization of Trust in International Relations. European Journal of International Relations, 8(3), 375-401.

[27] Holsti, Ole (1967). Cognitive Dynamics and Images of the Enemy: Dulles and Russia. In David Finlay, Ole Holsti and Richard Fagen (Ed.), Enemies in Politics (pp. 25-96). Chicago: Rand McNally.

[28] House of Commons Foreign Affairs Committee (2010). Global Security: UK -US Relations. London: The Stationery Office Limited.

[29] Intelligence and Security Committee (2007). Rendition. Retrieved from http://isc.independent.gov.uk/committeereports/special-reports

[30] John Major website. Retrieved from http://www.johnmajor.co.uk/speeches.html

[31] Kupchan, Charles A. (2010). How Enemies Become Friends: The Sources of Stable Peace. Princeton: Princeton University Press.

[32] Mercer, Jonathan (2005). Rationality and Psychology in International Politics. International Organization, 59 (1), 77 106.

[33] Moser, John E. (1999). Twisting the Lion's Tail: American Anglophobia between the World Wars. New York: New York University Press.

[34] Obama, Barack (2011, 25 May). The President's News Conference with Prime Minister David Cameron of the United Kingdom in London, England. The American Presidency Project. Retrieved from http://www.presidency.ucsb.edu/ws/index.php?pid=90445\&st=Obama\&st1=Cameron

[35] Obama, Barack (2012, 14 March). Remarks at a Welcoming Ceremony for Prime Minister David Cameron of the United Kingdom. The American Presidency Project. Retrieved from http://www.presidency.ucsb.edu/ws/index.php?pid=100034\&st=Obama\&st1=Cameron

[36] Oelsner, Andrea and Koschut, Simon (2014). Introduction. In Andrea Oelsner and Simon Koschut (Ed.). Friendship and International Relations (pp. 3-34). Basingstoke: Palgrave Macmillan.

[37] Parsons, Michael (2002). The Special Relationship 1945-1990: Myth or Reality. Études anglaises, 55, 456-471.

[38] Perkins, Bradford (1968). The Great Rapprochement: England and the United States, 1895-1914. New York: Atheneum.

[39] Pew Research Global Attitudes Project (2012) Opinion of the United States. Global Indicators Database. Retrieved from http://www.pewglobal.org/database/indicator/1/survey/1/

[40] Rasmussen, Jorgen and McCormick, James M. (1993) British Mass Perceptions of the Anglo-American Special Relationship. Political Science Quarterly, 108 (3), 515-541. 
[41] Reynolds, David (1986). A 'Special Relationship'? America, Britain and the International Order since the Second World War. International Affairs, 62 (1), 1-20.

[42] Reynolds, David (1989). 'Rethinking Anglo-American Relations', International Affairs, 65 (1), 89-111.

[43] Risse-Kappen, Thomas (1996) Collective Identity in a Democratic Community: The Case of NATO. In Peter J. Katzenstein (Ed.), The Culture of National Security: Norms and Identity in World Politics (pp. 357-399). New York: Columbia University Press.

[44] Self, Robert (2010). British Foreign \& Defence Policy since 1945: Challenges \& Dilemmas in a Changing World. London: Palgrave Macmillan.

[45] Strout, Cushing (1963). The American Image of the Old World. New York: Harper \& Row Publishers.

[46] The American Presidency Project. The Public Papers of the Presidents. Retrieved from http://www.presidency.ucsb.edu/ws/

[47] The Detainee Inquiry (2013) The Report of the Detainee Inquiry. Retrieved from http://isc.independent.gov.uk/committee-reports/special-reports

[48] Vucetic, Srdjan (2011). The Anglosphere: A Genealogy of a Racialized Identity in International Relations. Palo Alto: Stanford University Press.

[49] White House (2011, 25 May). Remarks by the President to Parliament in London, United Kingdom. Retrieved from http://www.whitehouse.gov/the-press-office/2011/05/25/remarks-president-parliament-london-united-kingdom

[50] White House (2012, 14 March). Remarks by President Obama and Prime Minister Cameron of the United Kingdom at Arrival Ceremony. Retrieved from http://www.whitehouse.gov/the-press-office/2012/03/14/remarks-presidentobama-and-prime-minister-cameron-united-kingdom-arriva

\section{Figure 1 Percentages of the USA's Favourable Feelings towards Its Four Allies, 1990-2010}

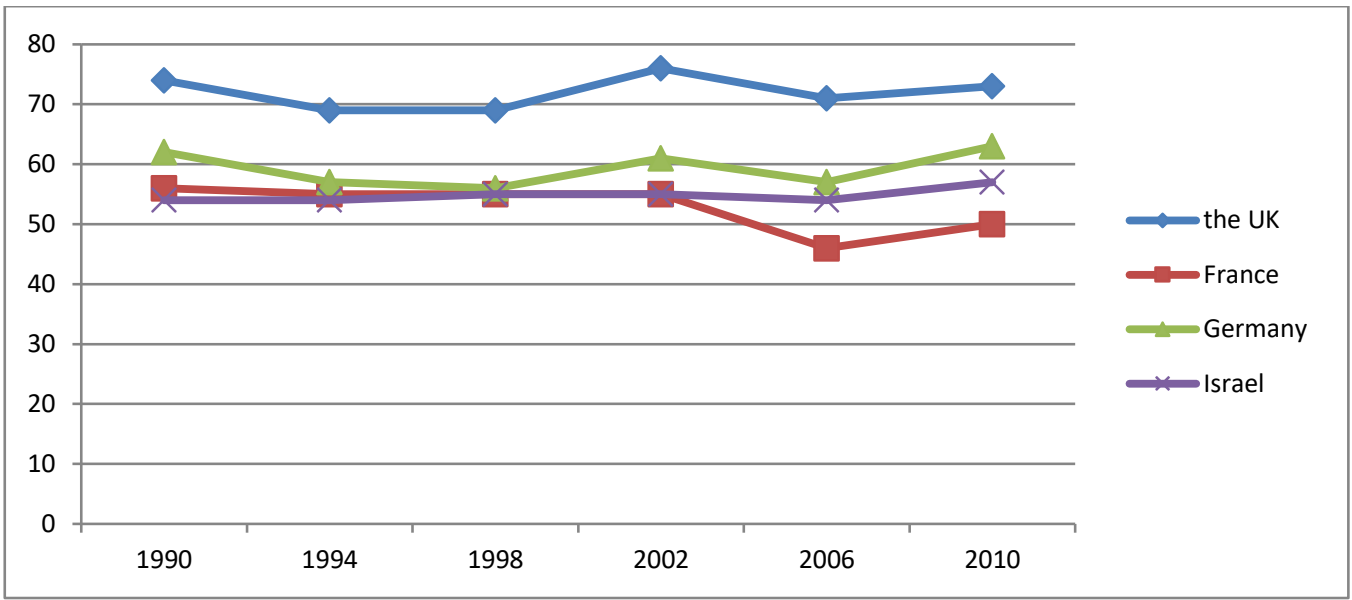

Source: Chicago Council on Global Affairs (2010). American Public Opinion and United States Foreign Policy Series. Retrieved from http://www.icpsr.umich.edu/icpsrweb/RCMD/series/00004 
Figure 2 Percentages of American People's Very/Mostly Favourable Foreign Countries, 2003-2013

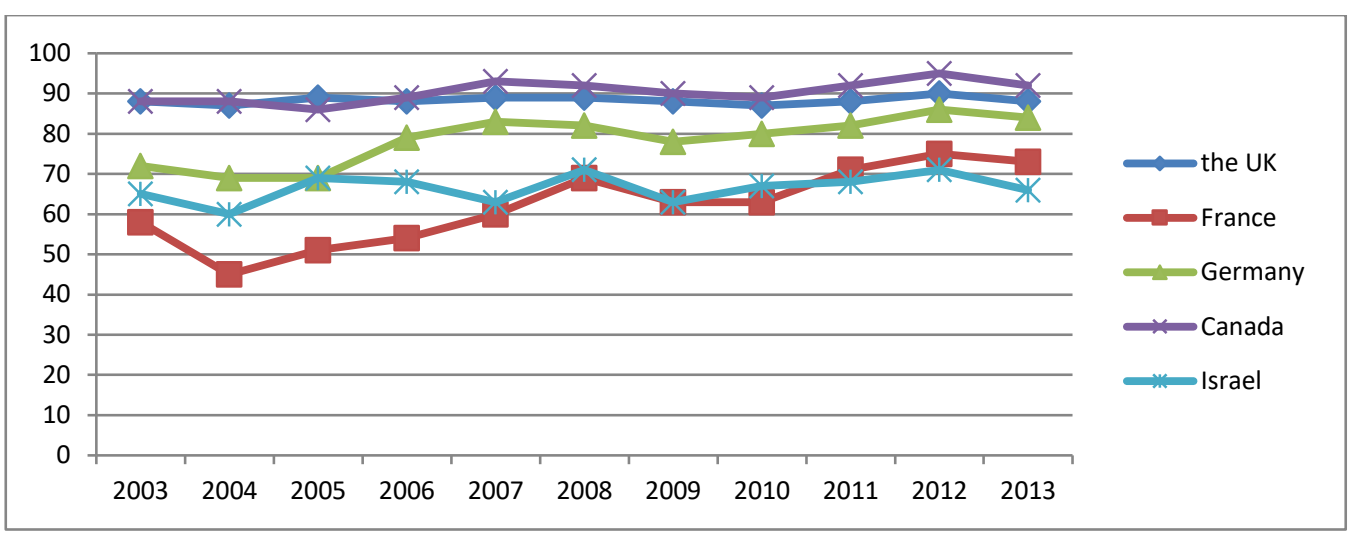

Source: Gallup Brain (2013). Gallup Poll Social Series: World Affairs, 2003-2013. Retrieved from https://institution.gallup.com/sorry/AccessDeniedlnstitution.aspx?r=/Brain/QuestionSearchResults.aspx

Figure 3 Percentages of the Favourable Feelings on the USA, 2002-2012

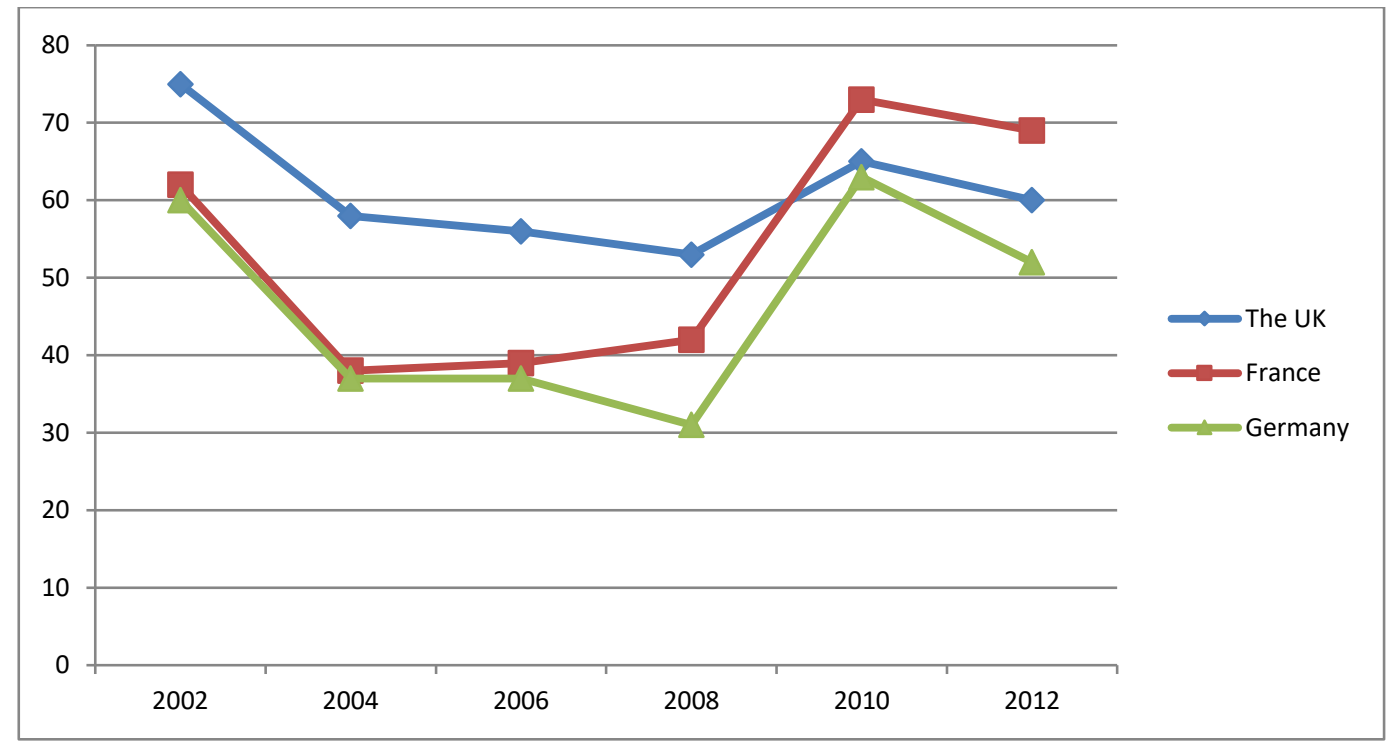

Source: Pew Research Global Attitudes Project (2012). Opinion of the United States. Global Indicators Database. Retrieved from http://www.pewglobal.org/database/indicator/1/survey/1/ 


\section{Figure 4 Words Used by Presidents and Prime Ministers to Describe the AASR}

\begin{tabular}{|c|c|}
\hline & Words used to describe the special relationship \\
\hline \multirow[t]{2}{*}{ President George H.W. Bush (1989-1993) } & a very, very special relationship \\
\hline & enduring special relationship \\
\hline \multirow{5}{*}{ President Bill Clinton (1993-2001) } & enduring partnership \\
\hline & a unique and enduring relationship \\
\hline & $\begin{array}{l}\text { an extraordinary relationship that unites us in a way never before } \\
\text { seen in the ties between two such great nations }\end{array}$ \\
\hline & an enduring alliance and a genuine friendship \\
\hline & the unique partnership \\
\hline \multirow{3}{*}{ President George W. Bush (2001-2009) } & the uniquely close relationship \\
\hline & a special and unique relationship \\
\hline & the unique alliance of values and common purpose \\
\hline \multirow{3}{*}{ President Barack Obama (2009- ) } & an extraordinarily special relationship \\
\hline & a truly special relationship \\
\hline & a unique relationship \\
\hline \multirow[b]{3}{*}{ Prime Minister John Major (1990-1997) } & the vital relationship \\
\hline & the longstanding relationship between my nation and your nation \\
\hline & a very close relationship, a very hard-edged relationship \\
\hline \multirow[b]{4}{*}{ Prime Minister Tony Blair (1997-2007) } & the great comradeship and partnership \\
\hline & It is a very strong relationship, a very special one \\
\hline & Ours is, indeed, a special and unique relationship \\
\hline & $\begin{array}{l}\text { It's an alliance of values. It's an alliance of common interests; It's } \\
\text { an alliance of common convictions and beliefs }\end{array}$ \\
\hline \multirow[b]{3}{*}{ Prime Minister Gordon Brown (2007-2010) } & the historic partnership of shared purpose between our countries \\
\hline & Britain's single most important bilateral relationship \\
\hline & a partnership of purpose that is borne out of shared values \\
\hline \multirow[b]{2}{*}{ Prime Minister David Cameron (2010- ) } & $\begin{array}{l}\text { This relationship isn't just an extraordinary special relationship. It } \\
\text { is also an absolutely essential relationship }\end{array}$ \\
\hline & $\begin{array}{l}\text { there are some countries whose alliance is a matter of } \\
\text { convenience, but ours is a matter of conviction }\end{array}$ \\
\hline
\end{tabular}

Source: Speeches of George H.W. Bush, Bill Clinton, George W. Bush, Barack Obama, John Major, Tony Blair, Gordon Brown and David Cameron, the Public Papers of the Presidents in the American Presidency Project, Retrieved from http://www.presidency.ucsb.edu/ws/; John Major website. Retrieved from http://www.johnmajor.co.uk/speeches.html

Figure 5 Contributors to the AASR from the Perspective of Presidents and Prime Ministers

\begin{tabular}{|l|l|}
\hline President George H.W. Bush & Contributors to the AASR \\
\hline President Bill Clinton & $\begin{array}{l}\text { common culture and civilization; rule of law; belief in the sanctity } \\
\text { of the individual; common values }\end{array}$ \\
\hline President George W. Bush & $\begin{array}{l}\text { common heritage; shared values; common aspirations; common } \\
\text { vision }\end{array}$ \\
\hline President Barack Obama & $\begin{array}{l}\text { common history; common values; common interests around the } \\
\text { globe; common language; common beliefs including open } \\
\text { societies ordered by moral conviction and private markets } \\
\text { humanized by compassionate government }\end{array}$ \\
\hline Prime Minister John Major & $\begin{array}{l}\text { common language; common culture; common legal system; } \\
\text { common heritage; common values; common interests; common } \\
\text { adherence to the rule of law; shared ideals and shared values }\end{array}$ \\
\hline & $\begin{array}{l}\text { ties of kinship, language and shared values; shared interests; } \\
\text { strong cultural ties; Anglo-Saxon sensibilities including respect }\end{array}$ \\
\hline
\end{tabular}




\begin{tabular}{|l|l|}
\hline Prime Minister Tony Blair & $\begin{array}{l}\text { for the individual, the rule of law, the virtues of prosperity and the } \\
\text { liberty of progress for all }\end{array}$ \\
\hline Prime Minister Gordon Brown & $\begin{array}{l}\text { shared language; shared outlook; the same values; the same } \\
\text { interests; common history }\end{array}$ \\
\hline Prime Minister David Cameron & $\begin{array}{l}\text { common interests; shared history; enduring values; the joint } \\
\text { inheritance of liberty }\end{array}$ \\
\hline $\begin{array}{l}\text { ties of culture and history and emotion; sentiment; shared } \\
\text { language; kindred spirits; shared interests; values }\end{array}$ \\
\hline
\end{tabular}

Source: Speeches of George H.W. Bush, Bill Clinton, George W. Bush, Barack Obama, John Major, Tony Blair, Gordon Brown and David Cameron, the Public Papers of the Presidents in the American Presidency Project. Retrieved from http://www.presidency.ucsb.edu/ws/; John Major website. Retrieved from http://www.johnmajor.co.uk/speeches.html

Figure 6 The Importance of the AASR in the Eyes of Presidents and Prime Ministers

\begin{tabular}{|c|c|}
\hline & The importance of the AASR \\
\hline President George H.W. Bush & "Our desire never deeper to build a free and peaceful world" \\
\hline President Bill Clinton & $\begin{array}{l}\text { "We live in a time of remarkable opportunity for peace and } \\
\text { prosperity, for open markets and open societies, for human } \\
\text { dignity and human decency. Together the United States and the } \\
\text { United Kingdom have helped to shape this hopeful moment in } \\
\text { our history" }\end{array}$ \\
\hline \multirow[b]{2}{*}{ President George W. Bush } & $\begin{array}{l}\text { "The United States and United Kingdom are acting together in a } \\
\text { noble cause. We're working together to make the world more } \\
\text { peaceful" }\end{array}$ \\
\hline & $\begin{array}{l}\text { "The close partnership between the United States and Great } \\
\text { Britain has been and remains essential to the peace and security } \\
\text { of all nations" }\end{array}$ \\
\hline \multirow{3}{*}{ President George W. Bush } & $\begin{array}{l}\text { The special relationship " is essential to the security and } \\
\text { prosperity of our two countries and the world" }\end{array}$ \\
\hline & $\begin{array}{l}\text { "Our alliance is essential to the security and prosperity that we } \\
\text { seek not only for our own citizens, but for people around the } \\
\text { world" }\end{array}$ \\
\hline & $\begin{array}{l}\text { "Our alliance will remain indispensable to the goal of a century } \\
\text { that is more peaceful, more prosperous, and more just" }\end{array}$ \\
\hline Prime Minister John Major & $\begin{array}{l}\text { "There is a great deal that we will wish to talk about that will } \\
\text { affect our future, your future and the future of people in other } \\
\text { countries around the world" }\end{array}$ \\
\hline \multirow[t]{2}{*}{ Prime Minister Tony Blair } & $\begin{array}{l}\text { "the relationship between the United States of America and } \\
\text { Britain is a relationship that is in the interests of our two } \\
\text { countries and in the interests of peace and stability of the wider } \\
\text { world" }\end{array}$ \\
\hline & $\begin{array}{l}\text { "It's a good alliance and a good partnership for our two } \\
\text { countries, and I believe, for the wider world" }\end{array}$ \\
\hline Prime Minister Gordon Brown & $\begin{array}{l}\text { "no international partnership has served the world better than the } \\
\text { special relationship between our two nations" }\end{array}$ \\
\hline Prime Minister David Cameron & $\begin{array}{l}\text { "And together, l'm confident that we can help secure the future } \\
\text { of our nations and the world for generations to come" }\end{array}$ \\
\hline
\end{tabular}

Source: Speeches of George H.W. Bush, Bill Clinton, George W. Bush, Barack Obama, John Major, Tony Blair, Gordon Brown and David Cameron, the Public Papers of the Presidents in the American Presidency Project. Retrieved from http://www.presidency.ucsb.edu/ws/; John Major website. Retrieved from http://www.johnmajor.co.uk/speeches.html 